Research Article

\title{
Study on Compaction Effect and Process of Reclaimed Soil of Nonmetallic Mines in Xinjiang, China
}

\author{
Kaikai Wang, ${ }^{1}$ Zizhao Zhang $\mathbb{D}^{1,2}$ Guobin Tang, ${ }^{1}$ Xiaodong Tan, ${ }^{1}$ Qianli Lv, ${ }^{1}$ \\ Fengjun Shao, ${ }^{1}$ and Xiaoping $\mathrm{Li}^{1}$ \\ ${ }^{1}$ School of Geological and Mining Engineering, Xinjiang University, Urumqi, Xinjiang 830046, China \\ ${ }^{2}$ School of Resources and Geosciences, China University of Mining and Technology, Xuzhou, Jiangsu 221116, China \\ Correspondence should be addressed to Zizhao Zhang; 253569481@qq.com
}

Received 16 January 2020; Accepted 30 March 2020; Published 25 April 2020

Academic Editor: Aniello Riccio

Copyright (C) 2020 Kaikai Wang et al. This is an open access article distributed under the Creative Commons Attribution License, which permits unrestricted use, distribution, and reproduction in any medium, provided the original work is properly cited.

Reclaimed soil is the key substrate for land reclamation and ecological restoration in the mine areas. The change of the density of reclaimed soil of the nonmetallic mines in Xinjiang during the land reclamation process was studied in this paper. Firstly, the in situ test method of static load was used to simulate the compaction of reclaimed soil with different thickness of overlying soil by different compaction times of mines reclamation machinery, and field in situ test compaction data were obtained. Then, the numerical simulation method was used to simulate the variation process of displacement and porosity at different depths for different thickness of the reclaimed soil under different compaction conditions. The numerical simulation and the in situ test results verified each other to acquire the compaction process and results of reclaimed soil under different compaction. The results showed that the numerical simulation results were consistent with the in situ test. The reclaimed soil thickness and compaction times were crucial factors affecting the compaction effect of the soil. The difference between the three times compaction and the uncompacted soil was obvious, and the effect of single compaction was weakened with the increase of compaction times. Under the same compaction action, the thicker the soil was, the less obvious the compaction effect would be. In the process of reclamation, the compaction effect of the surface part (at the depth of $10 \mathrm{~cm}$ ) was visible, and the amount of compression and springback was larger. The research results can provide a reference to the land reclamation of nonmetallic mines in Xinjiang, China.

\section{Introduction}

There are vast nonmetallic mineral resources in Xinjiang, and large-scale exploitation of mineral resources is bound to cause irreversible damages to the local ecological environment. The open-pit mining method is mainly adopted. Mines with open-pit mining form deep open pits and a large number of massive hard waste rocks, excavating and occupying numerous land resources (Figures 1 and 2). Mine enterprises must carry out land reclamation work after mine closure. In order to reclaim mines into grassland or woodland, covering soil is an reasonable measure to carry out for land reclamation work. In the process of this work, the reclamation machines will inevitably have a compaction effect on the surface soil, impacting on the quality of the reclaimed soil, thus holding back the ecological restoration of surface vegetation in the mining area. The surface soil of nonmetallic mines in Xinjiang is mostly sandy loam soil, and the soil texture is different from other places. Therefore, it is of great significance to grasp the compaction change of reclaimed soil in the process of land reclamation in Xinjiang.

Recently, studies on the soil compaction have yielded fruitful results, such as the effect of compaction on water infiltration in soil [1], the changes of physical and chemical properties of the reclaimed soil after compaction [2-9], the effect of using different reclamation materials on the soil compaction [10-12], the impact of compaction on the water content of soil [13-19], the effect of compaction on the soil structure $[20,21]$, and the effect of different compaction conditions on porosity of reclaimed soil [22]. According to 


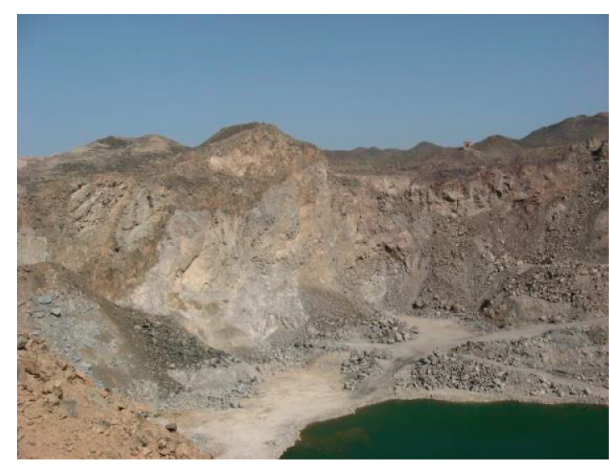

Figure 1: Open-pit mining area.

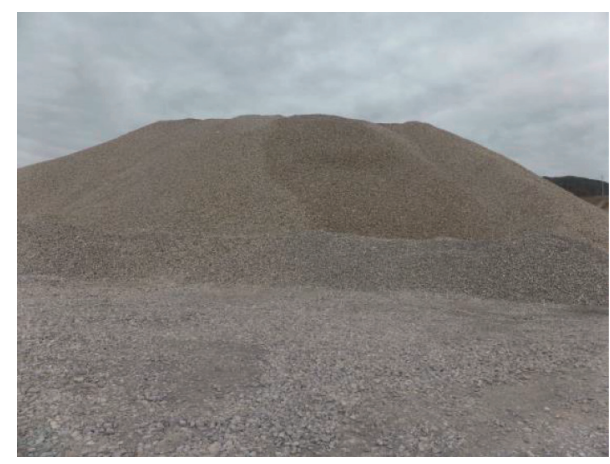

FIgURe 2: Waste rock piles.

the previous research results, it was found that studies on the compaction of soil were mostly concentrated on the agricultural field, and the compaction studies of the reclaimed soil in the mining area were mostly focusing on the soil reclamation in the coal mining area. In the past, the research on compaction simulation of reclaimed soil was mainly carried out through the field physical simulation test. The obtained soil compaction results could not reflect the change process of reclaimed soil under compaction. The reclaimed soil parameters obtained by physical simulation would also vary depending on the test method.

In view of the limitations of the past studies and the unique characteristics of the sandy soil of the nonmetallic mining zone, this study simulated the compaction effect of reclamation machinery on the reclaimed soil by the numerical simulation method. By comparing the numerical simulation results with the field physical simulation test results, the change process and law of reclaimed soil of nonmetallic mines in Xinjiang under different compaction were summarized, which provides a basis for land reclamation of nonmetallic mines in this region.

\section{Physical Simulation Results of Reclaimed Soil Compaction Test}

2.1. Experimental Materials. The reclaimed soil sample was taken from a limestone mining area in Dabancheng district, Urumqi, Xinjiang. The reclaimed soil was calcic brown soil and belonged to sandy loam. The bulk density of the reclaimed soil was $12.646 \mathrm{kN} / \mathrm{m}^{3}$ with $57.71 \%$ porosity and
$11.76 \%$ water content. The lower part of the reclaimed soil was backfilled with waste rocks from this limestone mining area.

2.2. Experimental Design. The widely used reclamation machines in Xinjiang are track-type bulldozers. In order to study the changes in the physical properties of the soil under different compaction effects of reclamation soil with different thicknesses, six 2 meter deep test barrels were set up (Figure 3).In these barrels, limestone waste rock was laid in the lower part (Figure 4), and $30 \mathrm{~cm}, 50 \mathrm{~cm}$, and $70 \mathrm{~cm}$ thick reclamation soil was laid in the upper layer. During the experiment, the flat load test method was used for 6 test barrels to simulate the instantaneous pressure of the NT855B280 crawler bulldozer on the ground (Figure 5). The simulated pressure was $33.7 \mathrm{kPa}$, and the compaction times were $0,1,3$, and 5 times (Figures 6 and 7 ). After compaction, in order to observe the changes in the physical properties of the soil, samples were taken at $10 \mathrm{~cm}, 30 \mathrm{~cm}, 50 \mathrm{~cm}$, and $70 \mathrm{~cm}$ in 6 test barrels. Three samples were taken with ring knifes at each depth. Finally, the collected soil samples were sent to laboratory for tests of natural density, moisture content, and porosity. The experimental process is detailed in the technical roadmap (Figure 8).

2.3. Experimental Data Compiling. A total of 16 groups of 48 soil samples were obtained in the compaction experiment. The topsoil with thickness of $50 \mathrm{~cm}$ and $70 \mathrm{~cm}$ was divided into 2 layers to collect samples. The topsoil with thickness of $30 \mathrm{~cm}$ at the depth of $30 \mathrm{~cm}$ could not be sampled as it was the interface between soil and waste rocks. Alternatively, samples at the depth of $10 \mathrm{~cm}$ were collected. The results of the compiled experimental data are shown in Table 1.

\section{Numerical Simulation of Reclaimed Soil Compaction Test}

3.1. Numerical Simulation Analysis Scheme. PFC2D is used to simulate the numerical simulation analysis. The thickness of the soil and the number of compaction were used as the dependent variables. The Mohr-Coulomb model was used as the yield criterion to analyze the effects of different reclamation methods (thickness of soil and compaction times) on porosity at different depths of reclaimed soil.

3.2. Computational Model. The particle size composition of the reclaimed soil calculation model is shown in Table 2. The soil sample of the compaction test was loose particles. The soil particle unit was defined as a rigid body, the model between the particles was defined as a linear elastic model, the model between the particle and the wall was defined as an elastic model, and the wall was defined as a confined rigid body. The model was the left and right and bottom boundary constraints, and the upper part was the free boundary of cyclic loading and unloading. The calculation model dimensions are shown in Tables 3 and 4 . Because the reclaimed soil was compacted for a short time, gravity was not considered in the calculation process. 


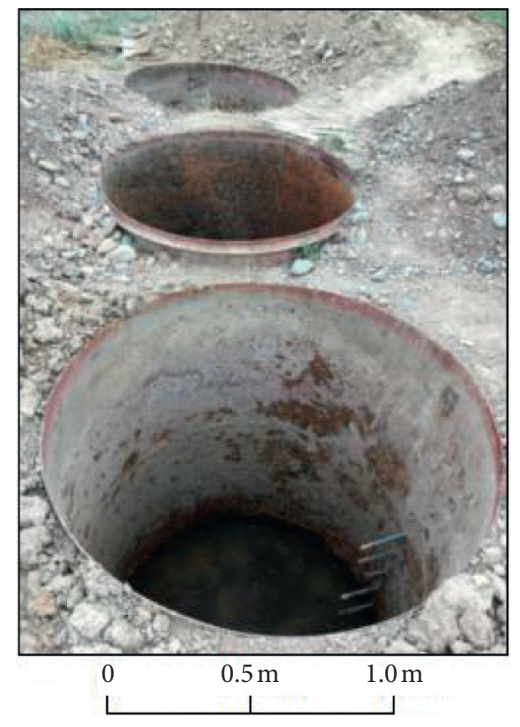

Figure 3: Empty cylindrical test barrels.

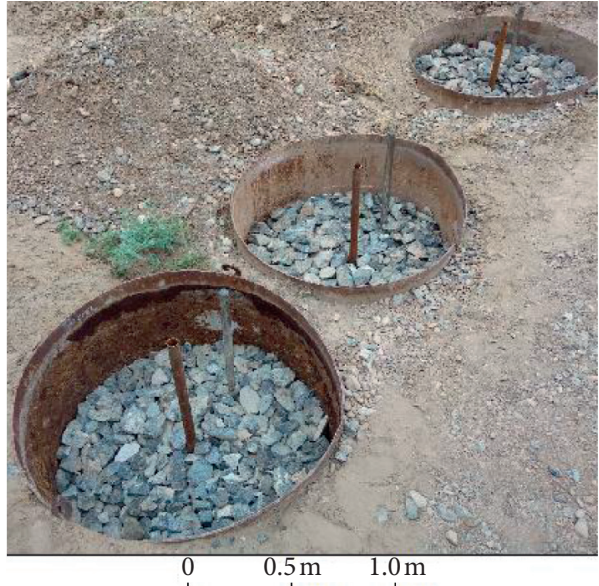

Figure 4: Backfilled waste rock at lower part of test barrels.

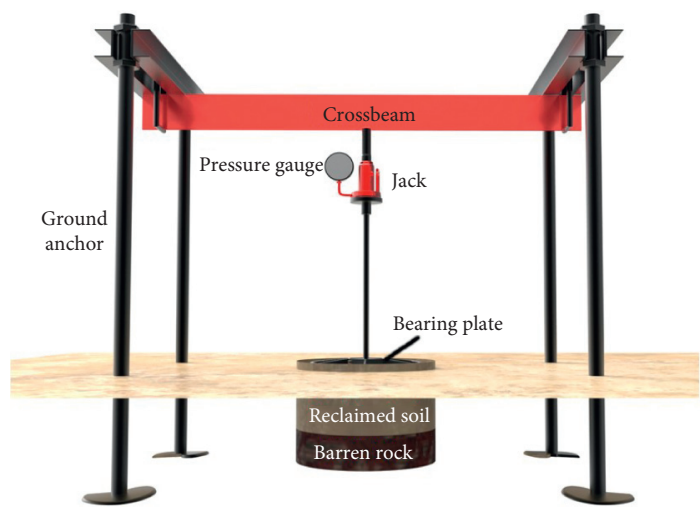

Figure 5: Illustration of the setup for plate load test.

3.3. Calculation Parameters. The calculation parameters in this numerical model were obtained from the results of in situ compaction test. The specific calculation parameters are shown in Table 5.

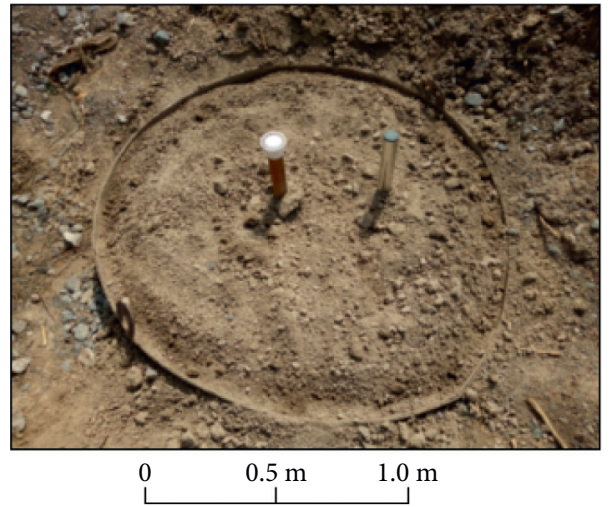

FIGURE 6: Uncompacted reclaimed soil test barrel.

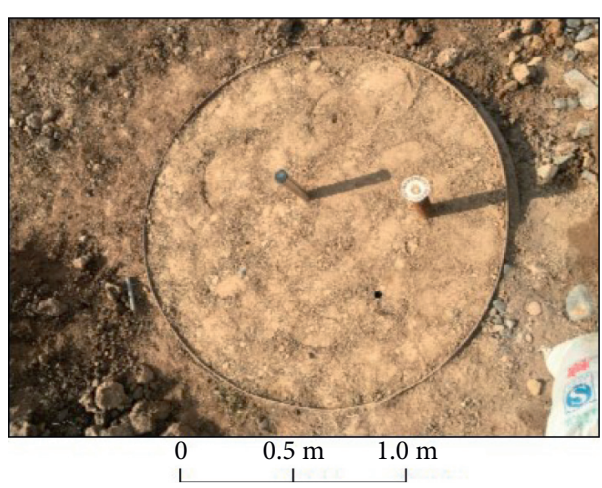

FIGURE 7: Reclaimed soil after one-compaction test barrel.

\subsection{Numerical Simulation Results}

3.4.1. Numerical Simulation Results of Covered $30 \mathrm{~cm}$ Soil Thickness under Compaction. The numerical simulation results of the soil thickness of $30 \mathrm{~cm}$ are shown in Figures 9-14 and summarized in Table 6. Table 6 shows that the soil particles have different degrees of subsidence after 


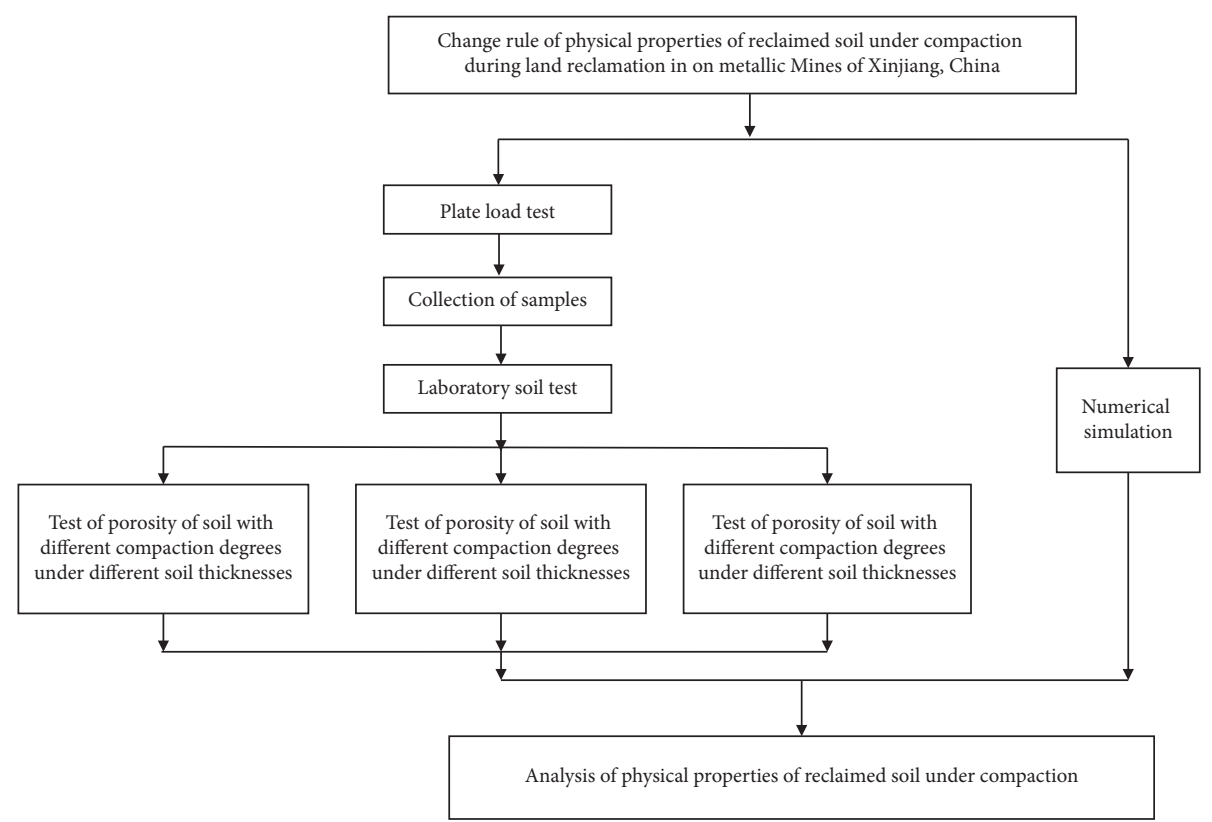

FIGURE 8: Technology roadmap.

TABLE 1: Results of the compaction experiment.

\begin{tabular}{|c|c|c|c|c|c|}
\hline $\begin{array}{l}\text { Thickness of topsoil } \\
(\mathrm{cm})\end{array}$ & $\begin{array}{l}\text { Times of } \\
\text { compaction }\end{array}$ & $\begin{array}{l}\text { Depth of sampling } \\
(\mathrm{cm})\end{array}$ & $\begin{array}{l}\text { Average of natural } \\
\text { density, } \rho\left(\mathrm{g} / \mathrm{cm}^{3}\right)\end{array}$ & $\begin{array}{c}\text { Average of water content in } \\
\text { mass, } \omega(\%)\end{array}$ & $\begin{array}{l}\text { Average of } \\
\text { porosity (\%) }\end{array}$ \\
\hline \multirow{7}{*}{70} & 0 & 10 & 1.290 & 11.76 & 57.71 \\
\hline & \multirow{2}{*}{1} & 10 & 1.425 & 11.41 & 53.15 \\
\hline & & 30 & 1.455 & 12.60 & 52.68 \\
\hline & \multirow{2}{*}{3} & 10 & 1.441 & 10.58 & 52.23 \\
\hline & & 30 & 1.457 & 12.29 & 52.47 \\
\hline & \multirow{2}{*}{5} & 10 & 1.447 & 9.70 & 51.70 \\
\hline & & 30 & 1.460 & 14.12 & 53.09 \\
\hline \multirow{6}{*}{50} & \multirow{2}{*}{1} & 10 & 1.470 & 14.23 & 52.87 \\
\hline & & 30 & 1.455 & 11.23 & 52.07 \\
\hline & \multirow{2}{*}{3} & 10 & 1.486 & 12.93 & 51.81 \\
\hline & & 30 & 1.483 & 11.67 & 51.34 \\
\hline & \multirow{2}{*}{5} & 10 & 1.490 & 11.17 & 50.92 \\
\hline & & 30 & 1.539 & 15.01 & 50.97 \\
\hline \multirow{3}{*}{30} & 1 & 10 & 1.512 & 11.72 & 50.42 \\
\hline & 3 & 10 & 1.552 & 13.36 & 49.83 \\
\hline & 5 & 10 & 1.556 & 12.71 & 49.42 \\
\hline
\end{tabular}

Only the average value of each experiment is listed. The water content is expressed in mass. The calculation method is that the mass of water in the soil is divided by the mass of dry soil. The calculation formula of the porosity is $n=1-\rho / 2.73 /(1+\omega)$.

TABLE 2: Particle size composition of reclaimed soil for numerical calculation model.

\begin{tabular}{llllll}
\hline Particle size (mm) & $0.1-0.25$ & $0.25-0.5$ & $0.5-1$ & $1-2$ & $2-5$ \\
Percentage content (\%) & 39.58 & 24.12 & 18.13 & 5.73 & 3.41 \\
\hline
\end{tabular}

TABLe 3: Dimension table of numerical calculation model.

\begin{tabular}{lc}
\hline $\begin{array}{l}\text { Model: length } \times \text { width } \\
(\mathrm{cm})\end{array}$ & $\begin{array}{c}\text { Measure the setting depth of a circle } \\
(\mathrm{cm})\end{array}$ \\
\hline $159.6 \times 10$ & 10 \\
$159.6 \times 30$ & 10,30 \\
$159.6 \times 70$ & 10,30 \\
\hline
\end{tabular}

The length of the model is equal to the diameter of the cylindrical test barrels (Figure 3). compaction. With the increase of compaction times, the maximum subsidence of reclaimed soil was gradually increased and the minimum porosity was gradually reduced. Figures 9 and 12 show that, after a compaction, the maximum subsidence of reclaimed soil was $3.2262 \mathrm{~cm}$ and the minimum porosity was 0.501 . Figures $13-14$ show the relationship between the porosity of soil samples and the number of times of compaction, such as 5 times compaction (Figure 14). The porosity of soil sample decreased with the 
TABLE 4: Compaction numerical simulation parameters.

\begin{tabular}{|c|c|c|c|c|}
\hline Soil thickness $(\mathrm{cm})$ & Compaction times & $\begin{array}{l}\text { Measuring the depth } \\
\text { of the circle }(\mathrm{cm})\end{array}$ & Initial porosity & $\begin{array}{l}\text { Natural initial density of } \\
\text { reclaimed soil }\left(\mathrm{g} / \mathrm{cm}^{3}\right)\end{array}$ \\
\hline 30 & $1,3,5$ & 10 & 0.5771 & 1.29 \\
\hline 50 & $1,3,5$ & 10,30 & 0.5771 & 1.29 \\
\hline 70 & $1,3,5$ & 10,30 & 0.5771 & 1.29 \\
\hline
\end{tabular}

TABLE 5: Physical parameters of compaction test numerical simulation.

\begin{tabular}{lccccc}
\hline $\begin{array}{l}\text { Simulated } \\
\text { porosity }\end{array}$ & $\begin{array}{c}\text { Equivalent modulus } \\
(\mathrm{kPa})\end{array}$ & $\begin{array}{c}\text { Ratio of normal stiffness to } \\
\text { tangential stiffness }\end{array}$ & $\begin{array}{c}\text { Friction coefficient between } \\
\text { particles }\end{array}$ & $\begin{array}{c}\text { Pressure } \\
(\mathrm{kPa})\end{array}$ & $\begin{array}{c}\text { Damping } \\
\text { ratio }\end{array}$ \\
\hline 0.2842 & $1.0 \times 10^{4}$ & 1 & 1.3 & 33.7 & 0.7 \\
\hline
\end{tabular}

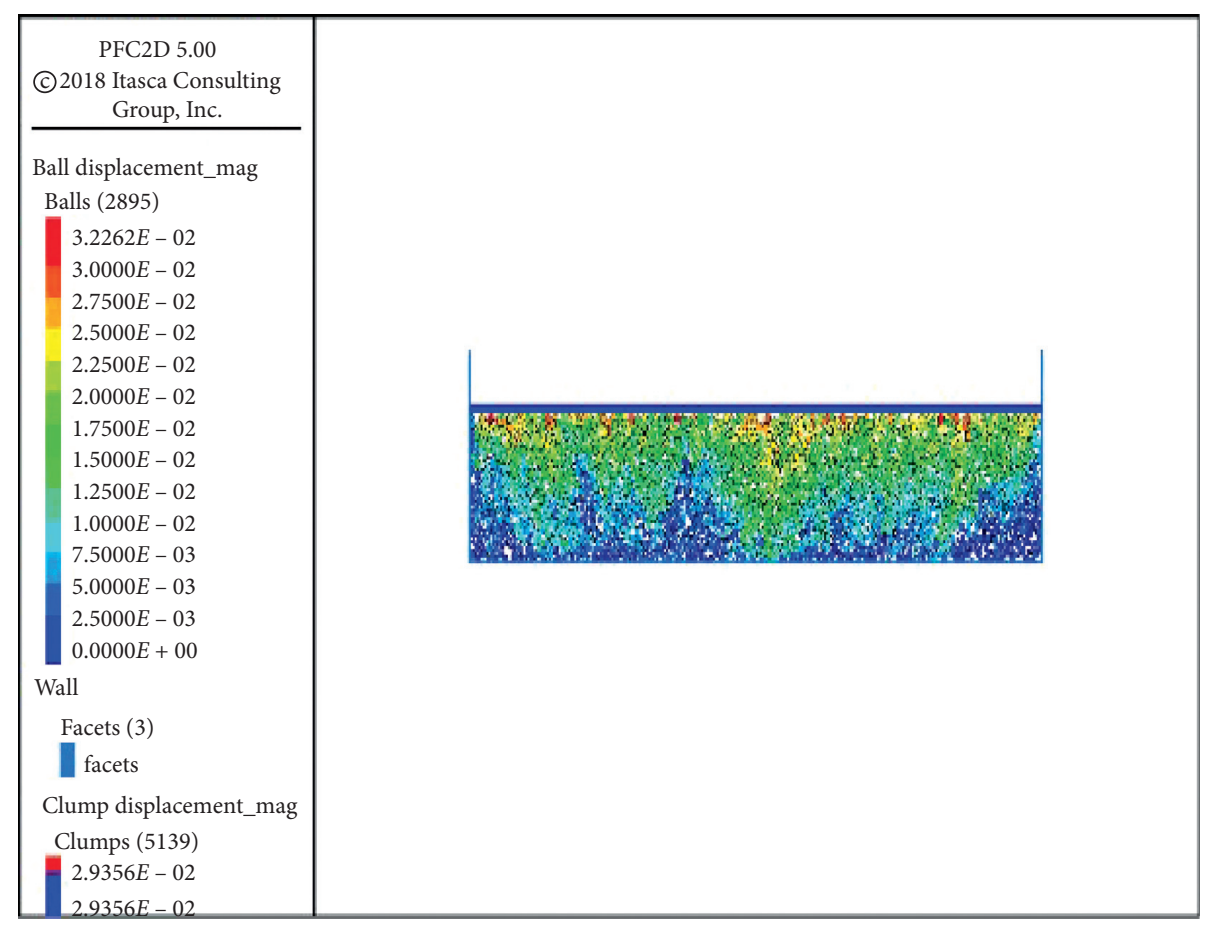

FIGURE 9: Discrete element particle migration map of $30 \mathrm{~cm}$ thick reclaimed soil with one compaction.

increase of the number of compactions. At the beginning of compaction, the change amplitude was obvious. After 5 times compaction, it stabilized. In our analysis, the main factors affecting soil porosity are the contact area of the soil particles and the arrangement of the particles. During the compaction process, changes in the soil structure lead to more compacted soil particles, which reduces the soil porosity. After the end of compaction, the soil structure rebounds after unloading, and the structure is basically stable, so the soil porosity also tends to be stable. The porosity obtained by the field compaction test was slightly larger than the minimum value of the numerical simulation, because the soil would rebound slightly during the sampling process. Thickness under Compaction. The numerical simulation results of the soil thickness of $50 \mathrm{~cm}$ are shown in Figures 15-20 and summarized in Table 7. It should be noted that the initial porosity at the depth of $30 \mathrm{~cm}$ was not 0.577 , which was due to the redistribution of particles in the initial stage and the filling of small particles into the pores of large particles at the initial stage that cause reduction in the pore rate. Table 7 shows that the law of subsidence of reclaimed soil after compaction was the same as that of covering soil thickness of $30 \mathrm{~cm}$, and the variation of minimum porosity was also reduced with the increase of compaction times. The porosity at the depth of $10 \mathrm{~cm}$ was finally lower than that of $30 \mathrm{~cm}$ after compaction, indicating that the surface compaction effect of the reclaimed soil was better. Figures 18-20 show that the porosity at the depth of $30 \mathrm{~cm}$ was generally less than $10 \mathrm{~cm}$ at the first time of compaction. This showed that the compaction effect at the depth of $30 \mathrm{~cm}$ was obvious 


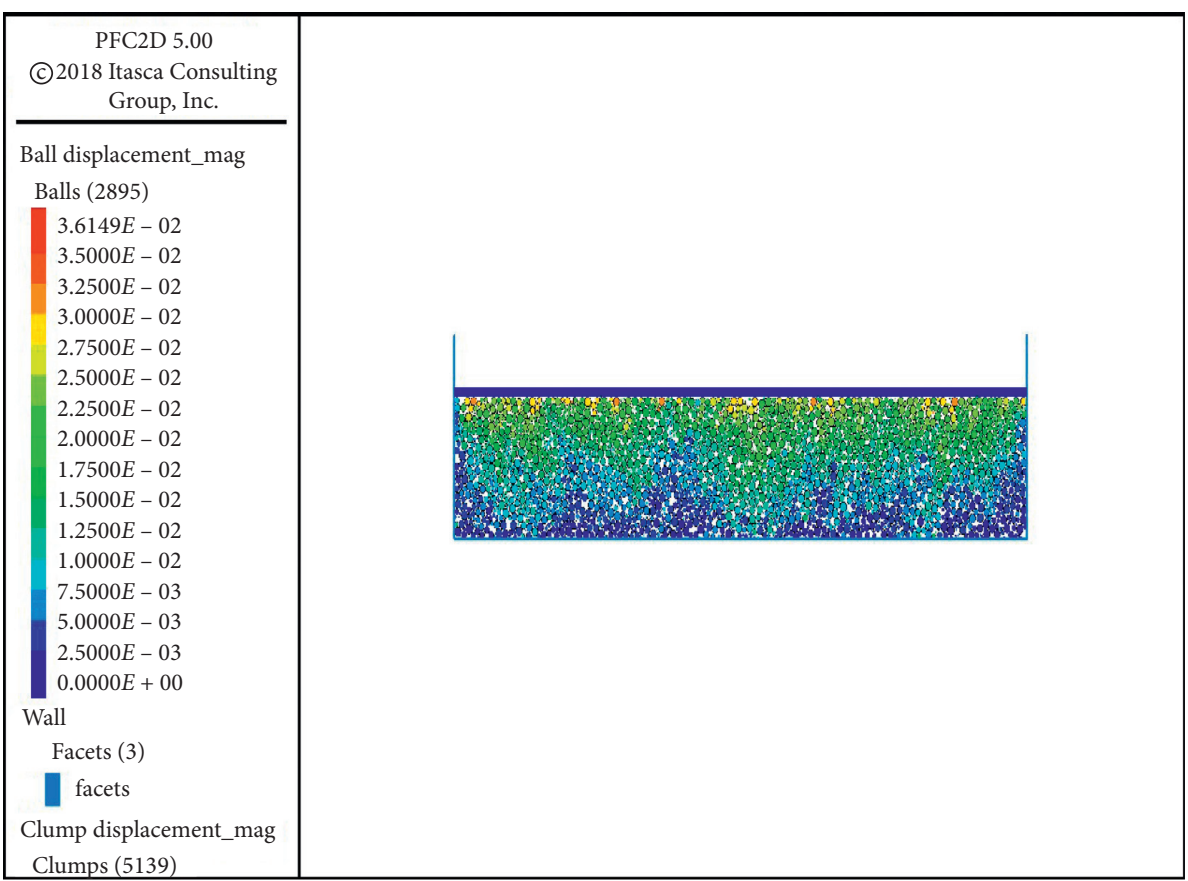

FIGURE 10: Discrete element particle migration map of $30 \mathrm{~cm}$ thick reclaimed soil with three compactions.

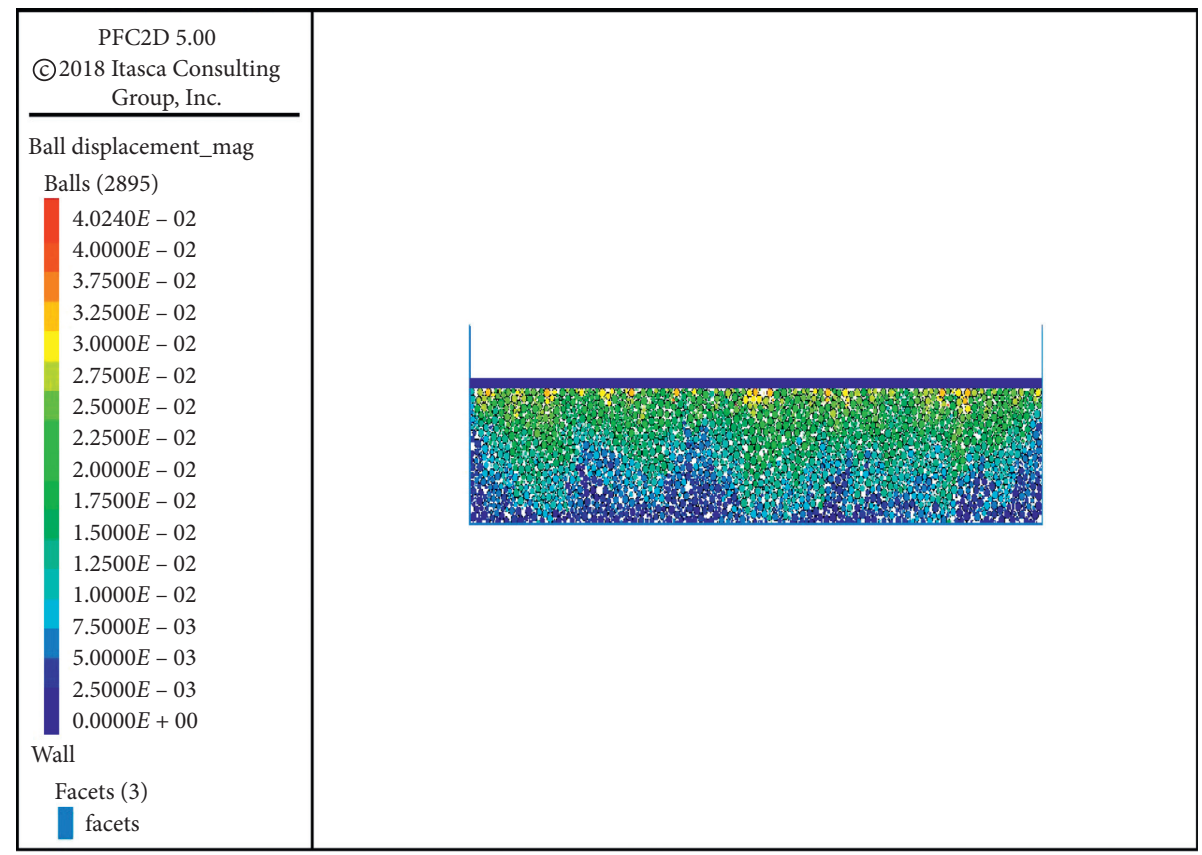

FIGURE 11: Discrete element particle migration map of $30 \mathrm{~cm}$ thick reclaimed soil with five compactions.

because of the up-down compression at the beginning of the compaction. With the increase of compaction times, the porosity at the depth of $10 \mathrm{~cm}$ was less than $30 \mathrm{~cm}$, which was consistent with the results of the in situ compaction test. After analysis, Under the same conditions, the porosity of the soil decreases with depth. During the compaction process, the surface soil absorbs little compaction energy, the soil structure undergoes greater deformation, and the structure becomes more compact.
Therefore, the soil in the shallow part has better compaction effect than the soil in the deep part.

3.4.3. Numerical Simulation Results of Covered $70 \mathrm{~cm}$ Soil Thickness under Compaction. The numerical simulation results of the soil thickness of $70 \mathrm{~cm}$ are shown in Figures 21-26 and summarized in Table 8, which shows that the law of subsidence of reclaimed soil after compaction was 


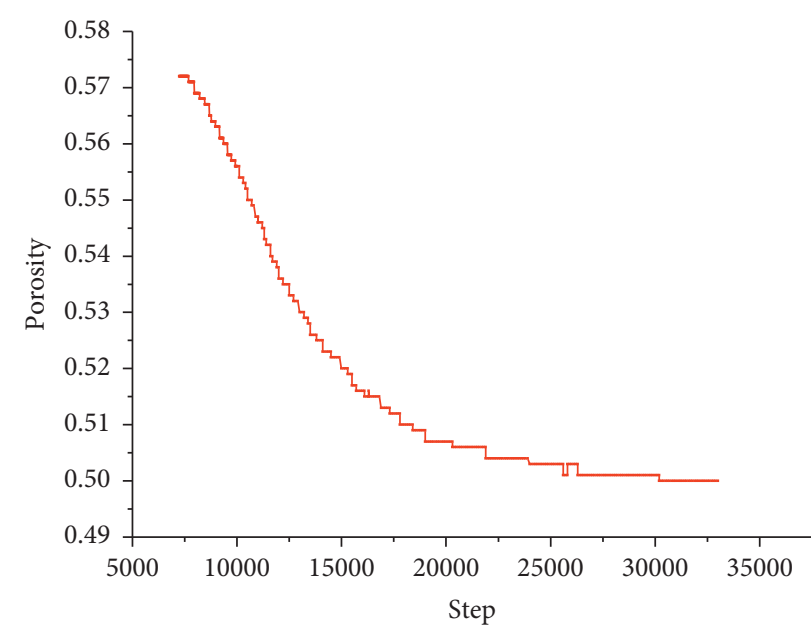

Depth of measurement

$-10 \mathrm{~cm}$

FIgURE 12: Curve of porosity change of $30 \mathrm{~cm}$ thick reclaimed soil with one compaction.

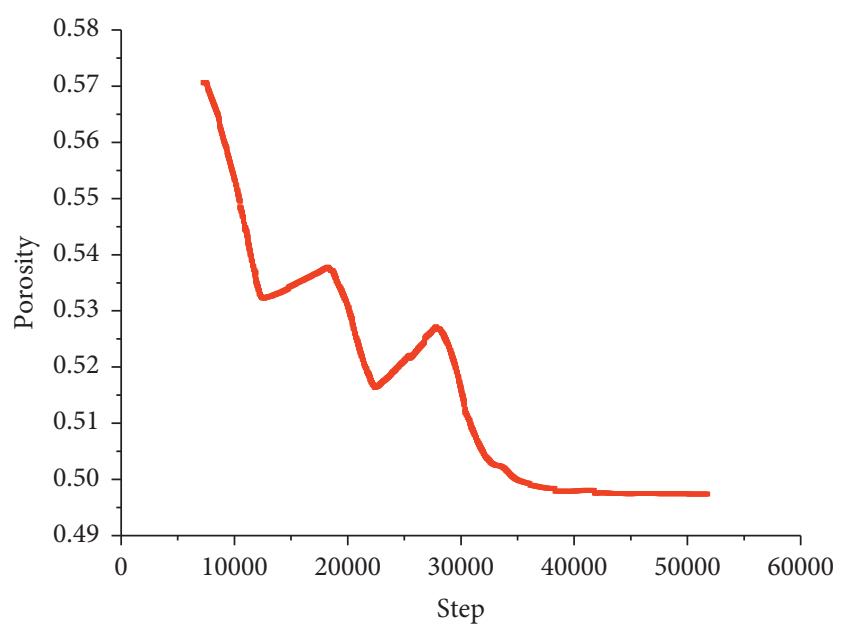

Depth of measurement $-10 \mathrm{~cm}$

FIGURE 13: Curve of porosity change of $30 \mathrm{~cm}$ thick reclaimed soil with three compactions.

the same as that of covering soils of $30 \mathrm{~cm}$ and $50 \mathrm{~cm}$, and the variation of minimum porosity was also reduced with the increase of compaction times. The minimum porosity at $10 \mathrm{~cm}$ depth was lower than $30 \mathrm{~cm}$ depth after compaction indicating that the compaction effect of the surface reclaimed soil was obvious. The numerical simulation porosity was also smaller than the in situ test result, and the difference reached the maximum; this was because that the soil was thickest and the springback of the soil was the largest. Figures 25 and 26 show that the porosity at the depth of $10 \mathrm{~cm}$ decreased and rebounded the most in each

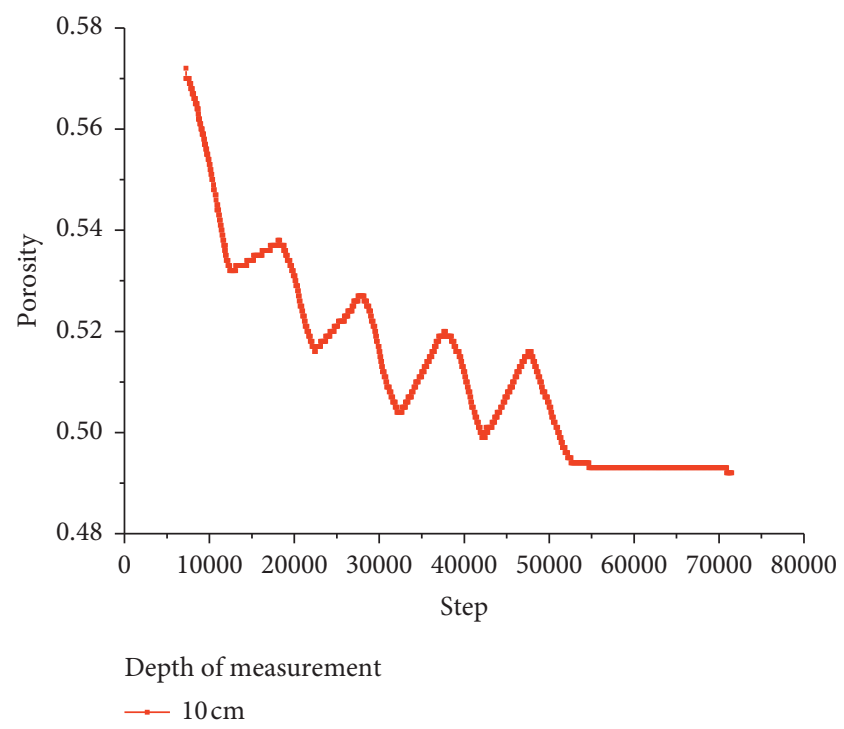

FIGURE 14: Curve of porosity change of $30 \mathrm{~cm}$ thick reclaimed soil with five compactions.

compaction process, stating that the compaction effect of the surface of the reclaimed soil was better under compaction. After analysis, the total thickness of the reclaimed soil is one of the main factors affecting the physical properties of the soil under compaction. Under the same conditions, the reclaimed soil with larger overall thickness is weaker in deformation due to compaction energy than the smaller thickness, so the compaction of different thickness of reclaimed soil at the same depth is more different, and the surface compaction of shallower overburden stronger. 
TABLE 6: Numerical simulation results for soil thickness of $30 \mathrm{~cm}$.

\begin{tabular}{|c|c|c|c|c|}
\hline $\begin{array}{l}\text { Compaction } \\
\text { times }\end{array}$ & $\begin{array}{l}\text { Maximum subsidence displacement of } \\
\text { soil particles after compaction }(\mathrm{cm})\end{array}$ & $\begin{array}{l}\text { Minimum porosity in } 10 \mathrm{~cm} \\
\text { depth of numerical simulation }\end{array}$ & $\begin{array}{c}\text { Porosity obtained by sampling } \\
\text { depth of } 10 \mathrm{~cm} \text { in field compaction } \\
\text { test }\end{array}$ & Difference \\
\hline 1 & 3.2262 & 0.501 & 0.5042 & 0.0032 \\
\hline 3 & 3.6149 & 0.498 & 0.4983 & 0.0003 \\
\hline 5 & 4.0240 & 0.494 & 0.4942 & 0.0002 \\
\hline
\end{tabular}

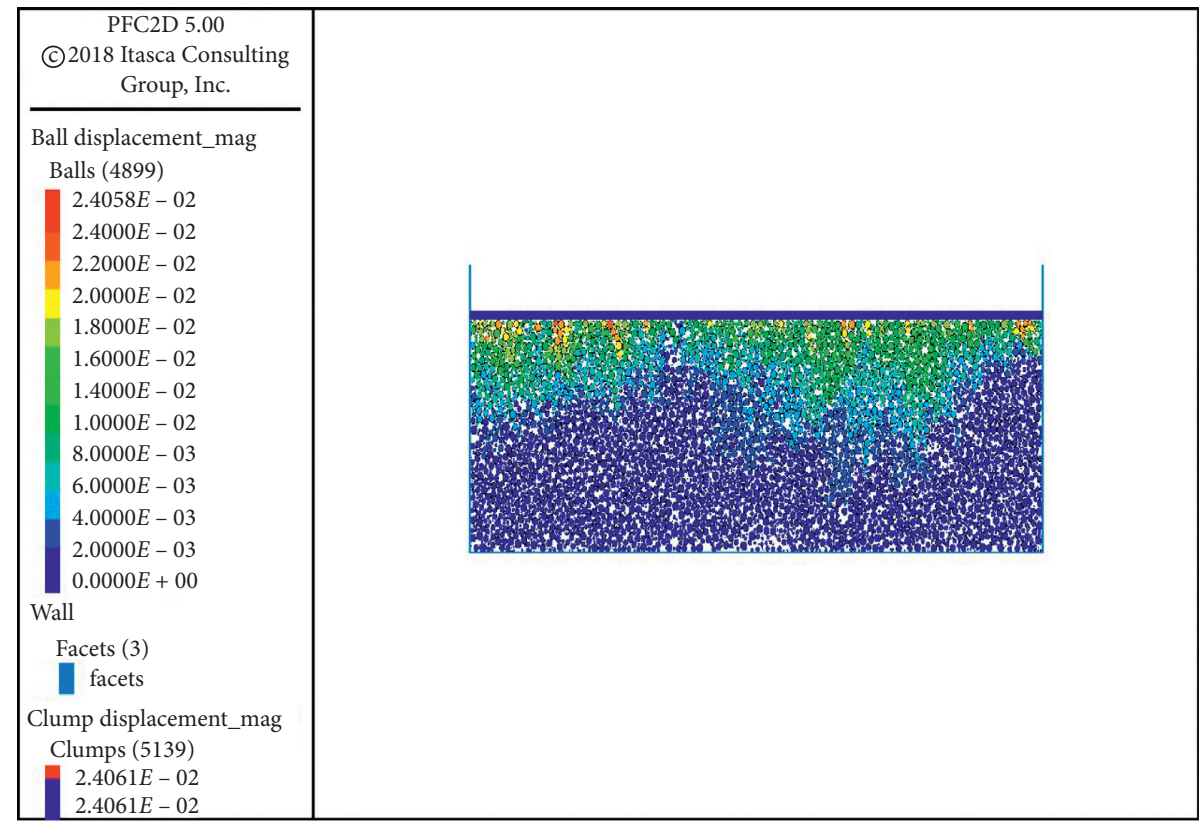

FIGURE 15: Discrete element particle migration map of $50 \mathrm{~cm}$ thick reclaimed soil with one compaction.

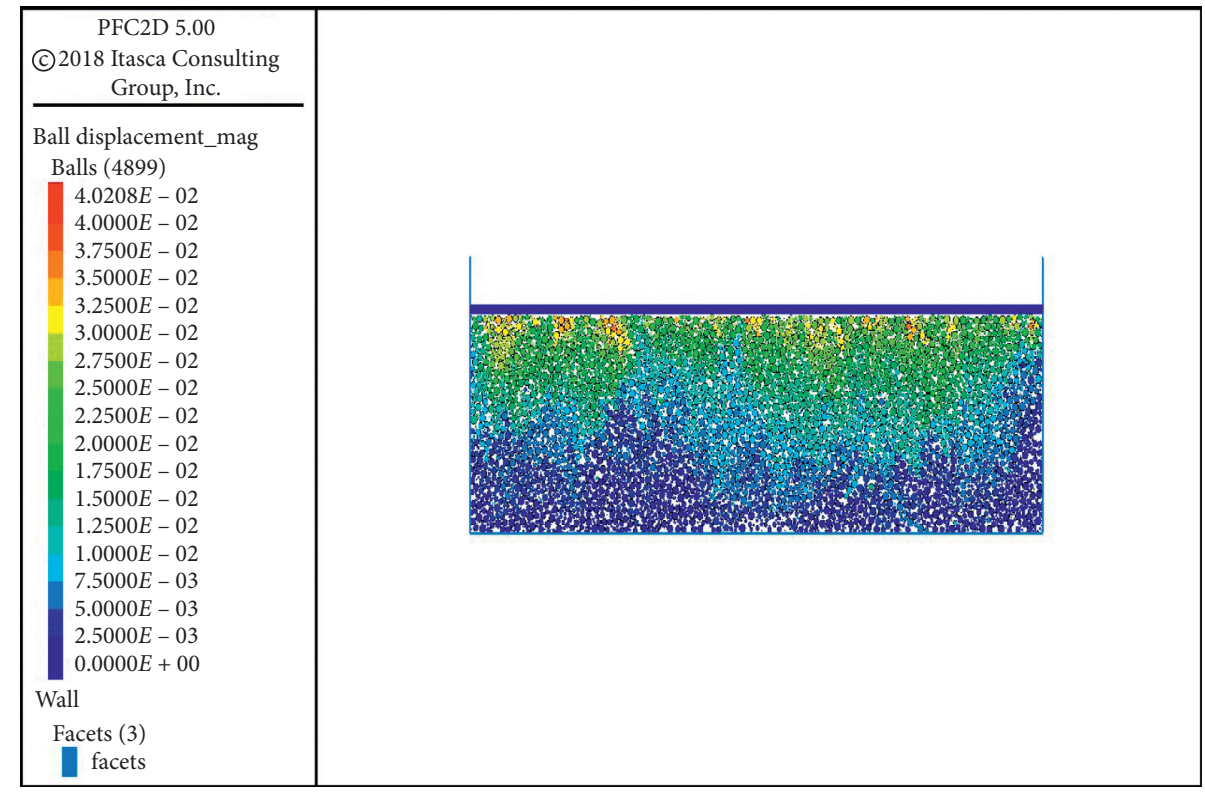

FIGURE 16: Discrete element particle migration map of $50 \mathrm{~cm}$ thick reclaimed soil with three compactions. 


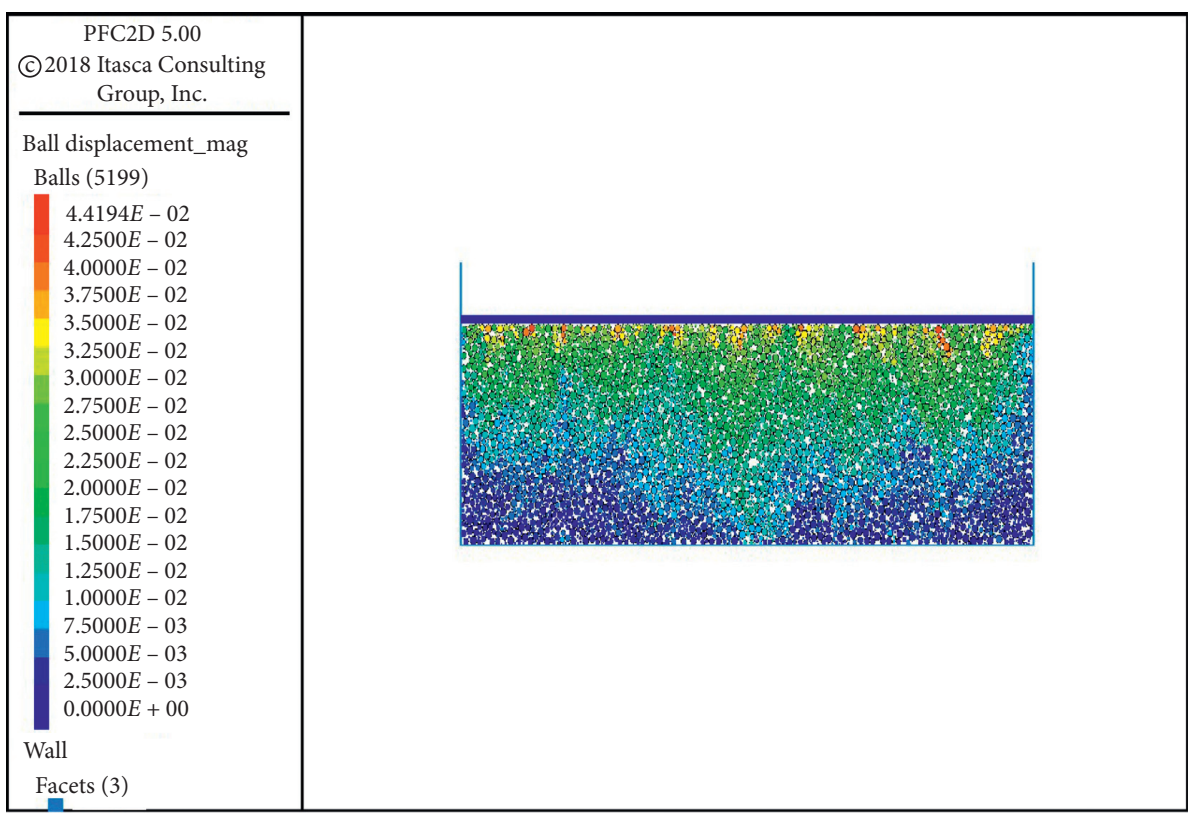

FIGURE 17: Discrete element particle migration map of $50 \mathrm{~cm}$ thick reclaimed soil with five compactions.

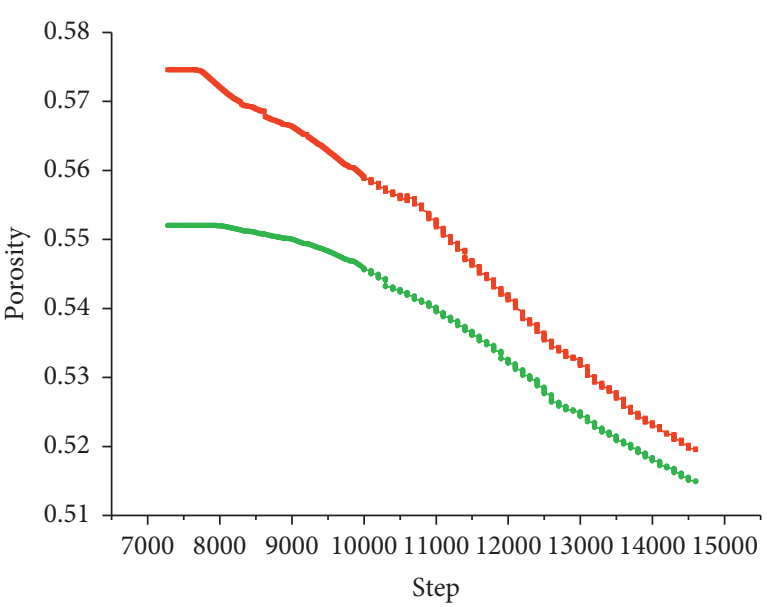

Depth of measurement

$\rightarrow 10 \mathrm{~cm}$

$\rightarrow 30 \mathrm{~cm}$

FIGURE 18: Curve of porosity change of $50 \mathrm{~cm}$ thick reclaimed soil with one compaction.

3.5. Comparison of Numerical Simulation and Physical Simulation Results. The data of numerical simulation results and field physical simulation results were sorted out as shown in Figures 27 and 28. Figures 27 and 28 show that the numerical simulation results are highly consistent with the field physical simulation results. As shown in Figure 27, the thicker the surface reclaimed is, the greater the porosity after compaction will be, which indicates that the overlying soil thickness is negatively correlated with the compaction effect during compaction. Figure 28 shows that the effect of

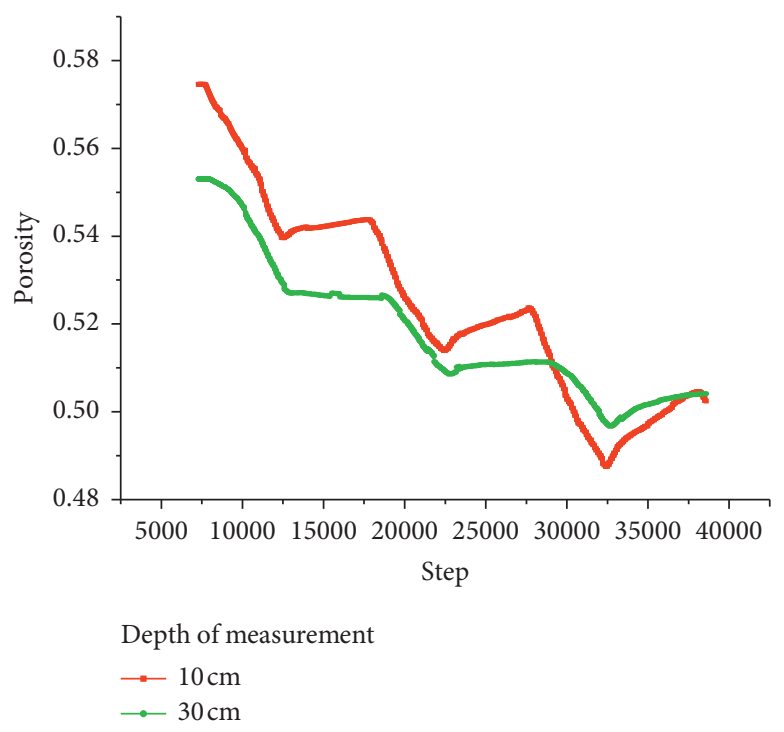

FIGURE 19: Curve of porosity change of $50 \mathrm{~cm}$ thick reclaimed soil with three compactions.

compacting three times is the most obvious, and the effect of single compaction is weakened with the increase of the number of compaction. The porosity at the depth of $30 \mathrm{~cm}$ is less than that at the depth of $10 \mathrm{~cm}$ at the first compaction, indicating that at the initial stage the compaction effect of the middle part of the reclaimed soil is obvious by the upper and lower extrusion. With the increase of the number of compaction, the porosity at the depth of $10 \mathrm{~cm}$ is less than $30 \mathrm{~cm}$, and the compaction effect on the surface of the soil is obvious. 


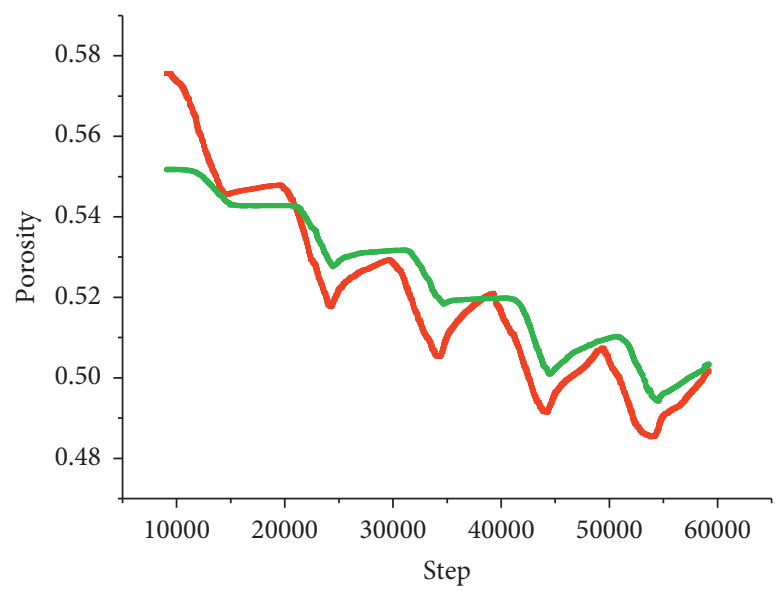

Depth of measurement

$$
\begin{aligned}
& -10 \mathrm{~cm} \\
& \because-30 \mathrm{~cm}
\end{aligned}
$$

FIGURE 20: Curve of porosity change of $50 \mathrm{~cm}$ thick reclaimed soil with five compactions.

\begin{tabular}{|c|c|c|c|c|c|c|c|}
\hline \multirow{2}{*}{$\begin{array}{l}\text { Compaction } \\
\text { times }\end{array}$} & \multirow{2}{*}{$\begin{array}{l}\text { Maximum subsidence displacement of soil } \\
\text { particles after compaction }(\mathrm{cm})\end{array}$} & \multicolumn{2}{|c|}{$\begin{array}{l}\text { Minimum porosity of } \\
\text { numerical simulation }\end{array}$} & \multicolumn{2}{|c|}{$\begin{array}{l}\text { Porosity obtained by } \\
\text { field compaction test }\end{array}$} & \multicolumn{2}{|c|}{ Difference } \\
\hline & & $\begin{array}{l}\text { Depth } \\
10 \mathrm{~cm}\end{array}$ & $\begin{array}{l}\text { Depth } \\
30 \mathrm{~cm}\end{array}$ & $\begin{array}{l}\text { Depth } \\
10 \mathrm{~cm}\end{array}$ & $\begin{array}{l}\text { Depth } \\
30 \mathrm{~cm}\end{array}$ & $\begin{array}{l}\text { Depth } \\
10 \mathrm{~cm}\end{array}$ & $\begin{array}{l}\text { Depth } \\
30 \mathrm{~cm}\end{array}$ \\
\hline 1 & 2.4058 & 0.52 & 0.5197 & 0.5287 & 0.5207 & 0.0087 & 0.001 \\
\hline 3 & 4.0208 & 0.49 & 0.5011 & 0.5187 & 0.5134 & 0.0287 & 0.0123 \\
\hline 5 & 4.4194 & 0.484 & 0.50 & 0.5092 & 0.5097 & 0.0252 & 0.0097 \\
\hline
\end{tabular}

TABLe 7: Numerical simulation results for soil thickness of $50 \mathrm{~cm}$.

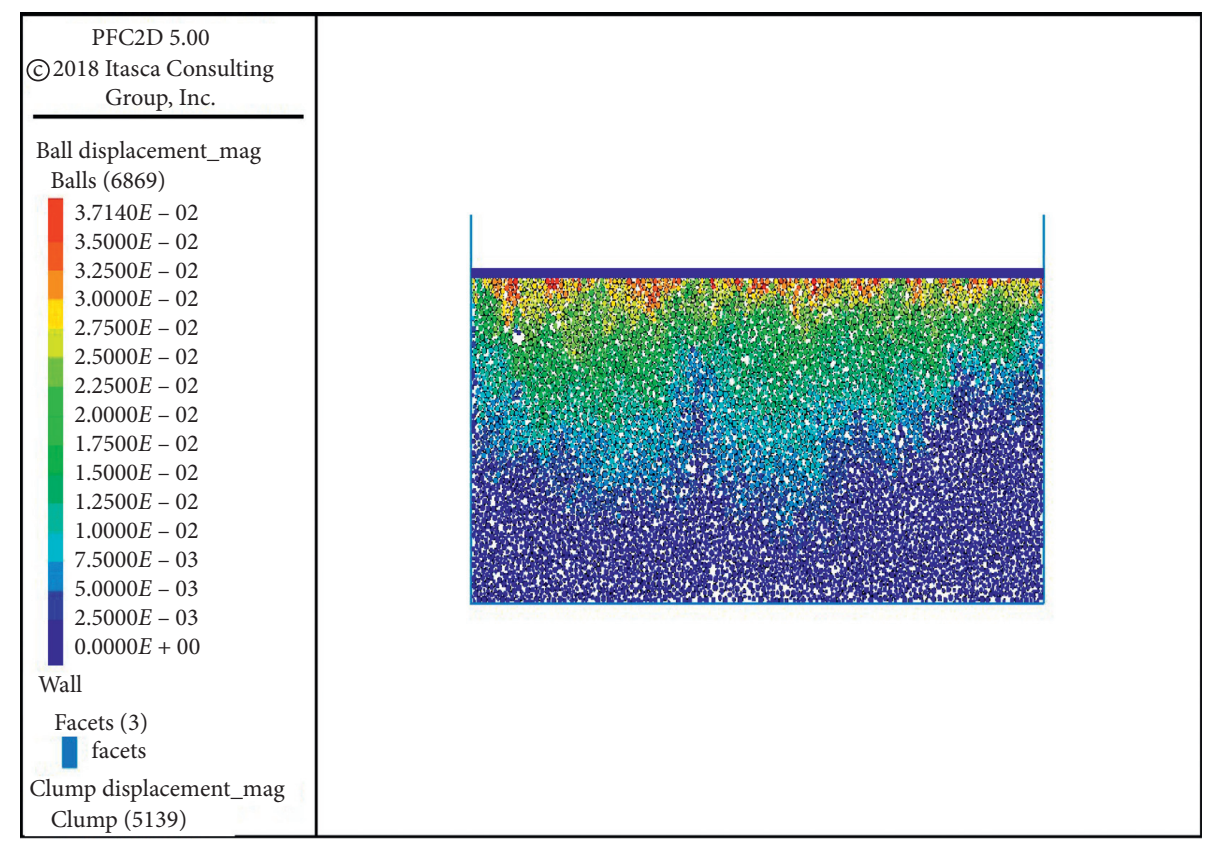

FIGURE 21: Discrete element particle migration map of $70 \mathrm{~cm}$ thick reclaimed soil with one compaction. 


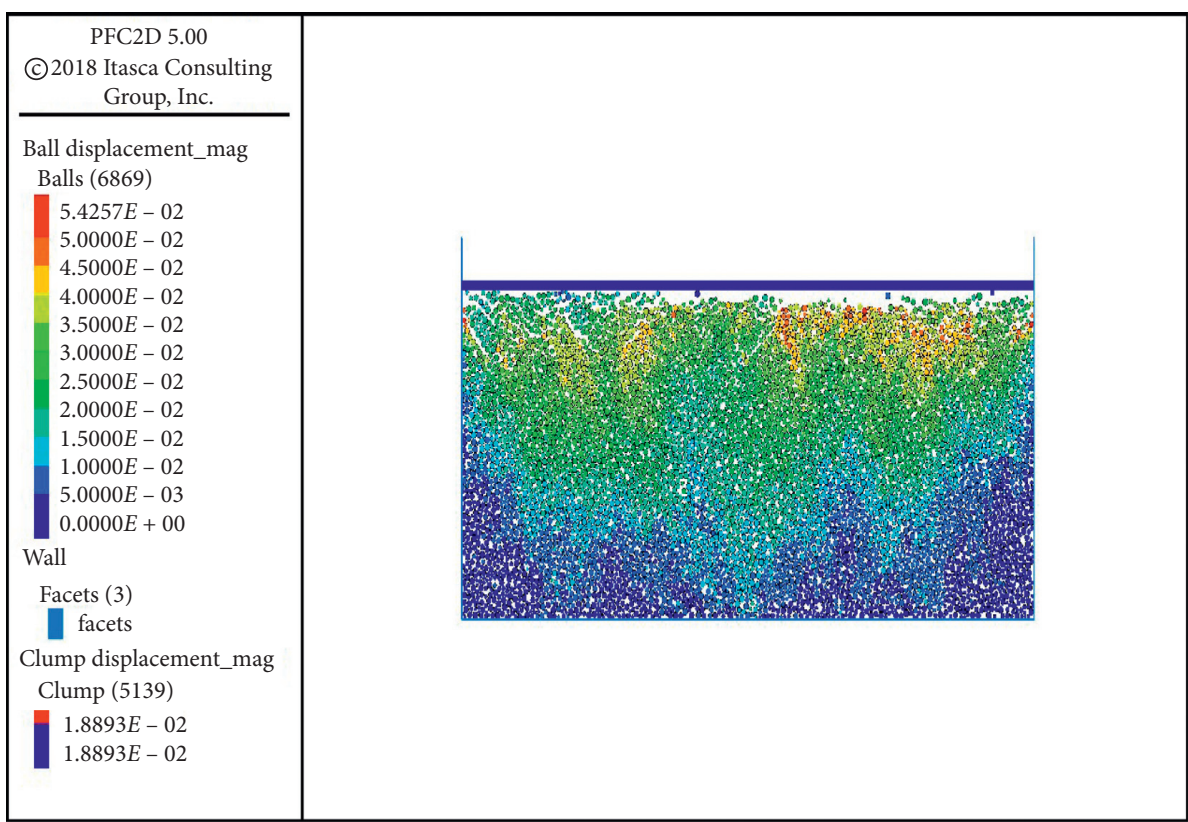

FIGURE 22: Discrete element particle migration map of $70 \mathrm{~cm}$ thick reclaimed soil with three compactions.

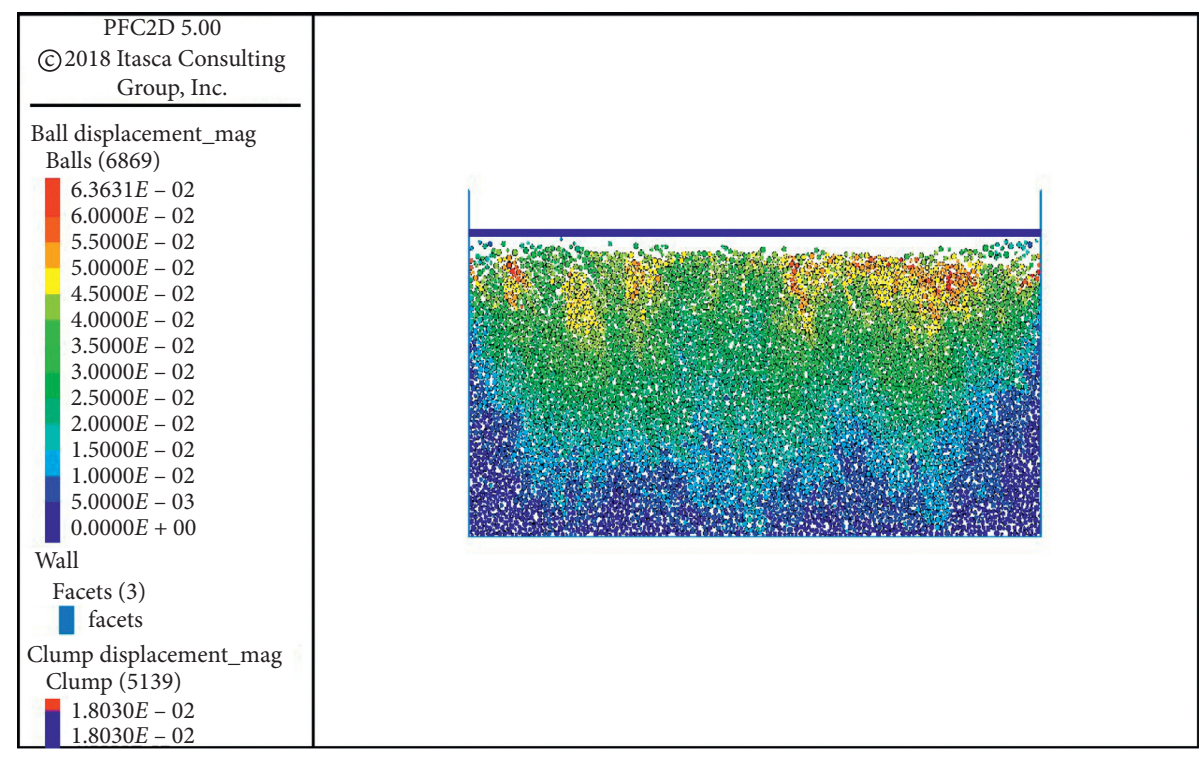

Figure 23: Discrete element particle migration map of $70 \mathrm{~cm}$ thick reclaimed soil with five compactions. 


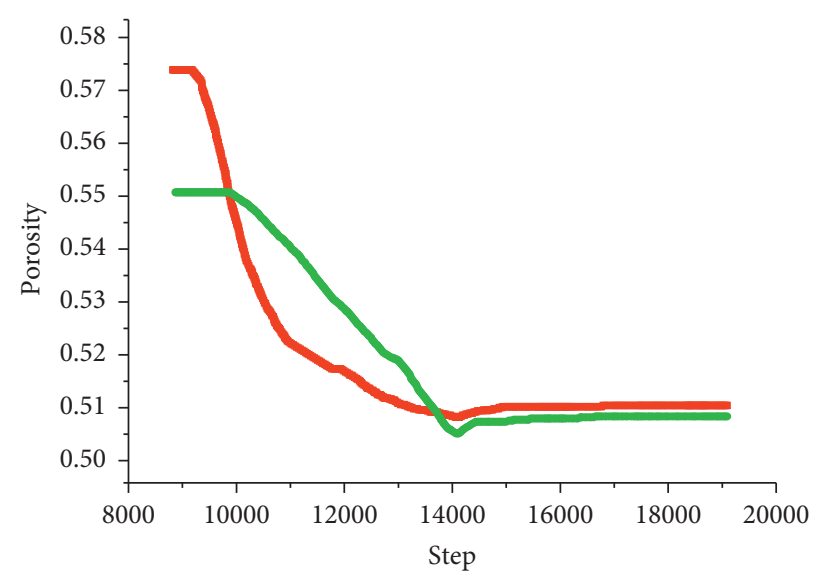

Depth of measurement

$\rightarrow-10 \mathrm{~cm}$

$\rightarrow 30 \mathrm{~cm}$

FIgURE 24: Curve of porosity change of $70 \mathrm{~cm}$ thick reclaimed soil with one compaction.

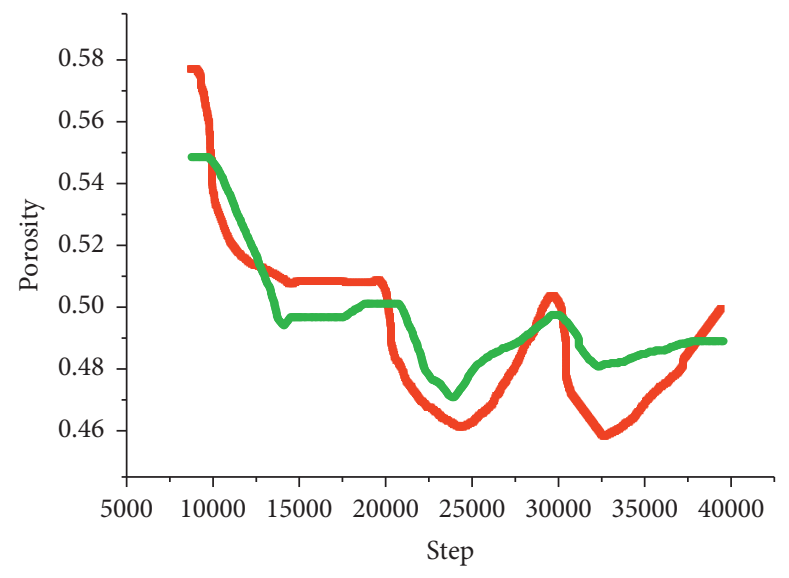

Depth of measurement

$\rightarrow 10 \mathrm{~cm}$

$\rightarrow 30 \mathrm{~cm}$

FIGURE 25: Curve of porosity change of $70 \mathrm{~cm}$ thick reclaimed soil with three compactions.

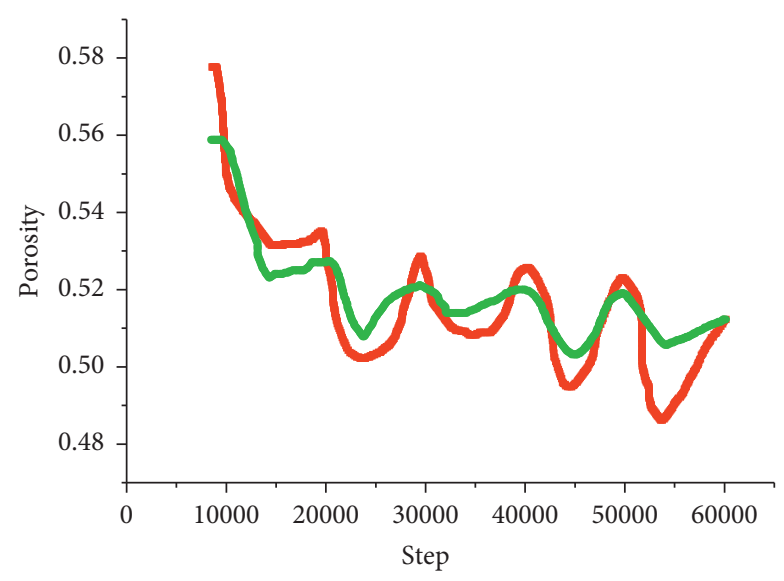

Depth of measurement

$$
\begin{aligned}
& -10 \mathrm{~cm} \\
& -30 \mathrm{~cm}
\end{aligned}
$$

FIGURE 26: Curve of porosity change of $70 \mathrm{~cm}$ thick reclaimed soil with five compactions. 
TABLE 8: Numerical simulation results for soil thickness $70 \mathrm{~cm}$.

\begin{tabular}{|c|c|c|c|c|c|c|c|}
\hline \multirow{2}{*}{$\begin{array}{l}\text { Compaction } \\
\text { times }\end{array}$} & \multirow{2}{*}{$\begin{array}{l}\text { Maximum subsidence displacement of soil } \\
\text { particles after compaction }(\mathrm{cm})\end{array}$} & \multicolumn{2}{|c|}{$\begin{array}{l}\text { Minimum porosity of } \\
\text { numerical simulation }\end{array}$} & \multicolumn{2}{|c|}{$\begin{array}{l}\text { Porosity obtained by } \\
\text { field compaction test }\end{array}$} & \multicolumn{2}{|c|}{ Difference } \\
\hline & & $\begin{array}{l}\text { Depth } \\
10 \mathrm{~cm}\end{array}$ & $\begin{array}{l}\text { Depth } \\
30 \mathrm{~cm}\end{array}$ & $\begin{array}{l}\text { Depth } \\
10 \mathrm{~cm}\end{array}$ & $\begin{array}{l}\text { Depth } \\
30 \mathrm{~cm}\end{array}$ & $\begin{array}{l}\text { Depth } \\
10 \mathrm{~cm}\end{array}$ & $\begin{array}{l}\text { Depth } \\
30 \mathrm{~cm}\end{array}$ \\
\hline 1 & 3.7147 & 0.528 & 0.525 & 0.5396 & 0.5268 & 0.0046 & 0.0018 \\
\hline 3 & 5.4257 & 0.502 & 0.514 & 0.5223 & 0.5247 & 0.0123 & 0.0107 \\
\hline 5 & 6.3631 & 0.488 & 0.508 & 0.5170 & 0.5309 & 0.015 & 0.0229 \\
\hline
\end{tabular}

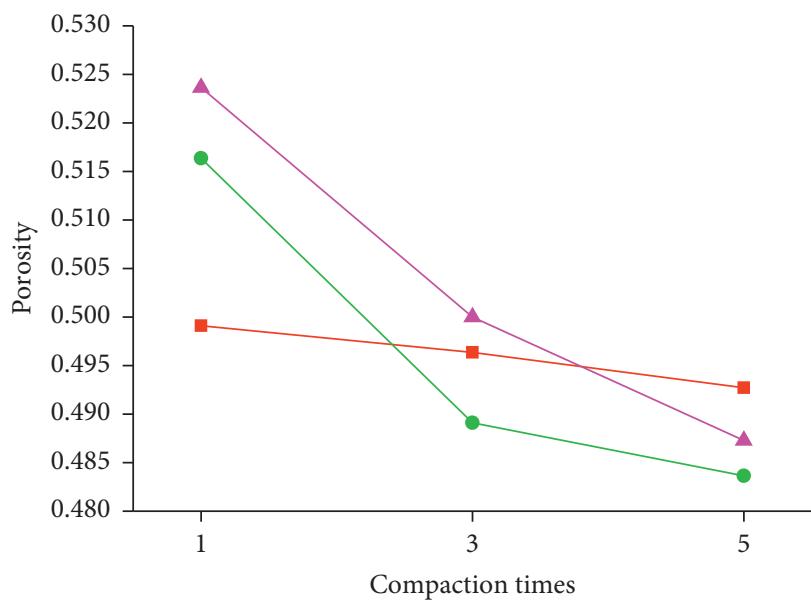

Soil thickness

$-30 \mathrm{~cm}$
$-50 \mathrm{~cm}$
$-70 \mathrm{~cm}$

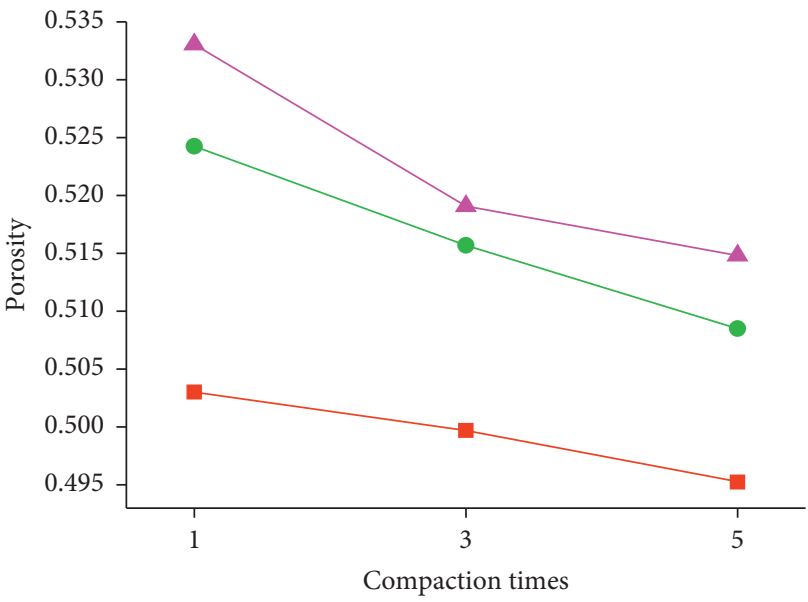

Soil thickness

$\rightarrow-30 \mathrm{~cm}$

$\rightarrow 50 \mathrm{~cm}$

$-70 \mathrm{~cm}$

(a)

(b)

FiguRE 27: Curves of porosity of different thicknesses of soil with different compaction times: the results of (a) numerical simulation and (b) physical simulation.

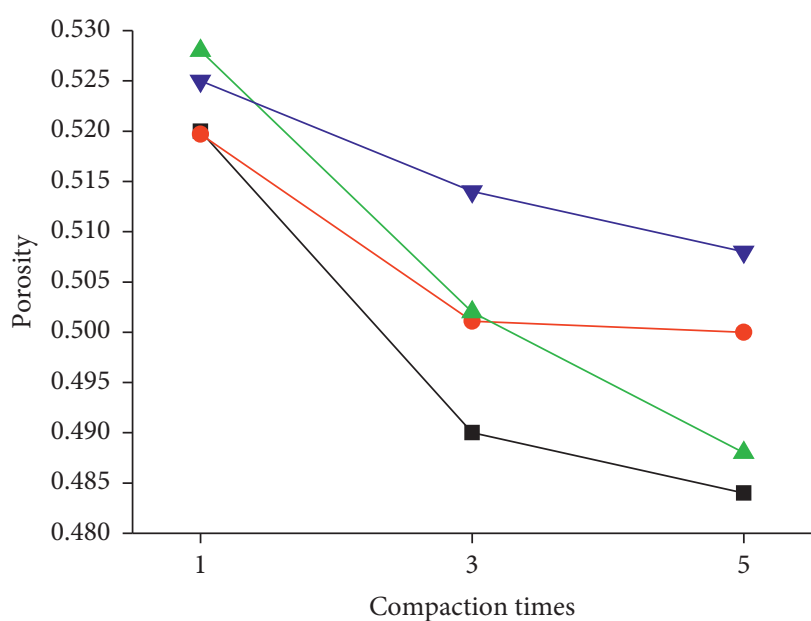

Soil thickness

$\rightarrow-50 \mathrm{~cm}$ (depth of mearsurement: $10 \mathrm{~cm}$ )

- $50 \mathrm{~cm}$ (depth of mearsurement: $30 \mathrm{~cm}$ )

$\triangle 70 \mathrm{~cm}$ (depth of mearsurement: $10 \mathrm{~cm}$ )

$\rightarrow 70 \mathrm{~cm}$ (depth of mearsurement: $30 \mathrm{~cm}$ )

(a)

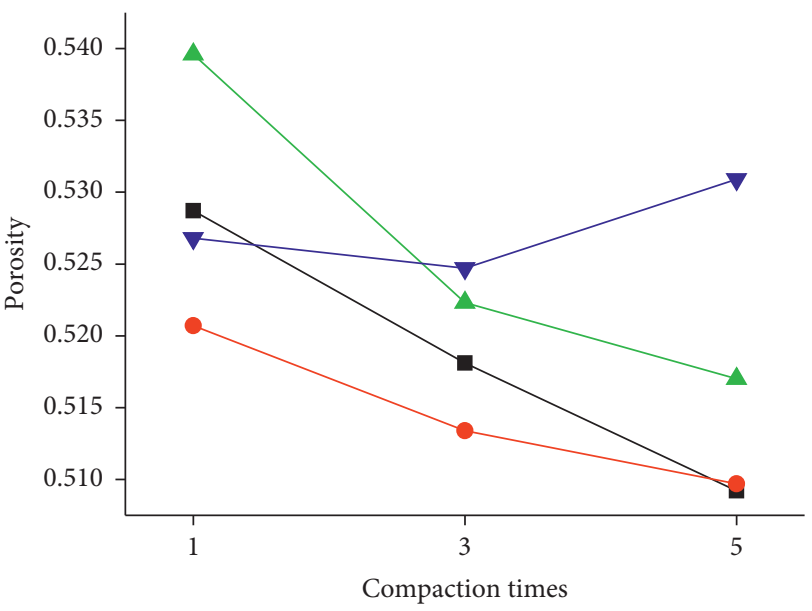

Soil thickness

$\rightarrow 50 \mathrm{~cm}$ (depth of mearsurement: $10 \mathrm{~cm}$ )

- $50 \mathrm{~cm}$ (depth of mearsurement: $30 \mathrm{~cm}$ )

$-70 \mathrm{~cm}$ (depth of mearsurement: $10 \mathrm{~cm}$ )

$\checkmark-70 \mathrm{~cm}$ (depth of mearsurement: $30 \mathrm{~cm}$ )

(b)

Figure 28: Curves of porosity of different thicknesses of soil and different depths with different compaction times: the results of (a) numerical simulation and (b) physical simulation. 


\section{Conclusions}

Studying the soil compaction effect of reclaimed soil is significant for ecological restoration of mining areas. In this paper, the compaction of reclaimed soils from nonmetallic mines in Xinjiang is studied. Based on the field physical simulation experiment, this paper mainly used the numerical simulation method to study the change process of porosity of reclaimed soils with different thickness under different compaction. Through the analysis of physical and numerical simulation results, it was concluded that the numerical simulation results of reclaimed soil compaction were consistent with the experimental results of physical simulation. The final porosity of reclaimed soil obtained by numerical simulation was smaller than physical simulation test result because of the springback of the reclaimed soil during the sampling process. The numerical simulation results were more realistic because they were not affected by the sampling process and the limitation of experimental methods. The effect of reclamation machinery on three times compaction of soil was significantly different from that of noncompaction. With the increase of compaction times, the effect of single compaction decreased. The thicker the overlying soil layer was, the less obvious the compaction effect was. The effect of reclamation machinery on the compaction of different depths was different. The compaction effect of reclamation machinery on the shallow part of reclaimed soil (depth $10 \mathrm{~cm}$ ) was the greatest. The porosity at the initial $30 \mathrm{~cm}$ depth was less than $10 \mathrm{~cm}$ depth. With the increase of compaction times, the porosity at the depth of $10 \mathrm{~cm}$ was less than that at the depth of $30 \mathrm{~cm}$, which indicated that the effect of surface compaction is obvious.

\section{Data Availability}

The data used to support the findings of this study are included within the article. All data included in this study are available upon request by contact with the corresponding author.

\section{Conflicts of Interest}

The authors declare that there are no conflicts of interest.

\section{Authors' Contributions}

Z.Z. conceived the main idea of the paper and designed the test scheme; K.W., F.S., G.T., and X.L. performed the test scheme; K.W. and G.T. analyzed the data; Z.Z. wrote the paper; W.S. did a lot work to modify figures and proofread the revised version. D.T. and Q.L. reviewed and seriously revised the article after it was withdrawn.

\section{Acknowledgments}

This research was funded by the Natural Science Foundation of Xinjiang (grant no. 2018D01C061).

\section{Supplementary Materials}

The supplementary material is a graphical abstract to illustrate the main content of this article. (Supplementary Materials)

\section{References}

[1] M. Mossadeghi-Bjo"rklund, J. Arvidsson, T. Keller et al., "Effects of subsoil compaction on hydraulic properties and preferential flow in a Swedish clay soil," Soil and Tillage Research, vol. 156, pp. 91-98, 2016.

[2] X. Li, Z. Hu, J. Li, W. Zhang, and N. Liu, "Research progress of reclaimed soil quality in mining subsidence area," Transactions of the CSAE, vol. 23, no. 6, pp. 276-280, 2007.

[3] M. A. Hamza and W. K. Anderson, "Soil compaction in cropping systems," Soil and Tillage Research, vol. 82, no. 2, pp. 121-145, 2005.

[4] X. Min, X. Li, and X. Li, "Influence of mechanical compaction on reclaimed soil particle size distribution multifractal characteristics," Transactions of the Chinese Society of Agricultural Engineering (Transactions of the CSAE), vol. 33, no. 20, pp. 274-283, 2017.

[5] X. Jiao, L. Wang, C. Lu, C. Gao, E. Dong, and X. Liu, "Effects of two reclamation methodologies of coal mining subsidence on soil physical and chemical properties," Journal of Soil and Water Conservation, vol. 24, no. 4, pp. 123-125, 2009.

[6] X. Huang, X. Li, and N. Liu, "Effects of different construction machinery on particle composition of reclaimed soil in coal mining area," Soil Water Conserv, vol. 28, no. 01, pp. 136-140, 2014.

[7] B. Schäffer, W. Attinger, and R. Schulin, "Compaction of restored soil by heavy agricultural machinery-soil physical and mechanical aspects," Soil and Tillage Research, vol. 93, no. 1, pp. 28-43, 2007.

[8] M. Pagliai, A. Marsili, P. Servadio, N. Vignozzi, and S. Pellegrini, "Changes in some physical properties of a clay soil in Central Italy following the passage of rubber tracked and wheeled tractors of medium power," Soil and Tillage Research, vol. 73, no. 1-2, pp. 119-129, 2003.

[9] W. Zhang, X. Min, X. Sun, and J. Zheng, "Effect of different machinery and compaction on the physical property of reclamation soil in coal area," J.Shandong Land and Resources, vol. 33, no. 3, pp. 64-67, 2017.

[10] K. Kim and S. Chun, "Finite element analysis to simulate the effect of impact rollers for estimating the influence depth of soil compaction," KSCE Journal of Civil Engineering, vol. 20, no. 7, pp. 2692-2701, 2016.

[11] P. Götze, J. Rücknagel, A. Jacobs, B. Märländer, H.-J. Koch, and O. Christen, "Environmental impacts of different crop rotations in terms of soil compaction," Journal of Environmental Management, vol. 181, pp. 54-63, 2016.

[12] J. Sun, X.. , Li., Li. H, and X. Hang, "Soil composition mechanism research of different reclamation material in coal mining subsidence area," China Coal Journal, vol. 38, no. 12, pp. 2215-2220, 2013.

[13] P. De'fossez, G. Richard, H. Boizard, and M. F. O’Sullivan, "Modeling change in soil compaction due to agricultural traffic as function of soil water content," Geoderma, vol. 116, no. 1, pp. 89-105, 2003.

[14] A. Trautner and J. Arvidsson, "Subsoil compaction caused by machineryz traffic on a Swedish Eutric Cambisol at different soil water contents," Soil and Tillage Research, vol. 73, no. 3, pp. 107-118, 2003. 
[15] H. G. Yavuzcan, D. Matthies, and H. Auernhammer, "Vulnerability of Bavarian silty loam soil to compaction under heavy wheel traffic: impacts of tillage method and soil water content," Soil and Tillage Research, vol. 84, no. 2, pp. 200-215, 2005.

[16] K. Saffih-Hdadi, P. Défossez, G. Richard, Y.-J. Cui, A.-M. Tang, and V. Chaplain, "A method for predicting soil susceptibility to the compaction of surface layers as a function of water content and bulk density," Soil and Tillage Research, vol. 105, no. 1, pp. 96-103, 2009.

[17] C. Cholaky, M. Cisneros, and R. Balbuena, "Field performance of a winged scarifier as a function of soil compaction and water content," Chilean Journal of Agricultural Research, vol. 70, no. 1, pp. 150-158, 2010.

[18] A. J. N. D. Silva and M. S. V. Cabeda, "Compactação e compressibilidade do solo sob sistemas de manejo e níveis de umidade," Revista Brasileira de Ciência do Solo, vol. 30, no. 6, pp. 921-930, 2006.

[19] K. Ghadernejad, G. Shahgholi, A. Mardani, and H. G. Chiyaneh, "Prediction effect of farmyard manure, multiple passes and moisture content on clay soil compaction using adaptive neuro-fuzzy inference system," Journal of Terramechanics, vol. 77, pp. 49-57, 2018.

[20] E. J. B. V. Chiyaneh, C. D. Mccullough, and M. A. Lund, "Importance of topography and topsoil selection and storage in successfully rehabilitating post-closure sand mines featuring pit lakes.Mining Technology," Transactions of the Institutions of Mining and Metallurgy, vol. 121, no. 1, pp. 139-150, 2012.

[21] A. F. Christensen, H. He, M. F. Dyck et al., "In situ measurement of snowmelt infiltration under various topsoil cap thicknesses on a reclaimed site," Canadian Journal of Soil Science, vol. 93, no. 4, pp. 497-510, 2013.

[22] Z. Zhang, G. Tang, and J. Zhu, "Study on compaction of reclaimed soil of nonmetallic mining area in Northern Foothills of Tianshan Mountains in Xinjiang, China," Advances in Materials Science and Engineering, vol. 2019, Article ID 2834019, 10 pages, 2019. 